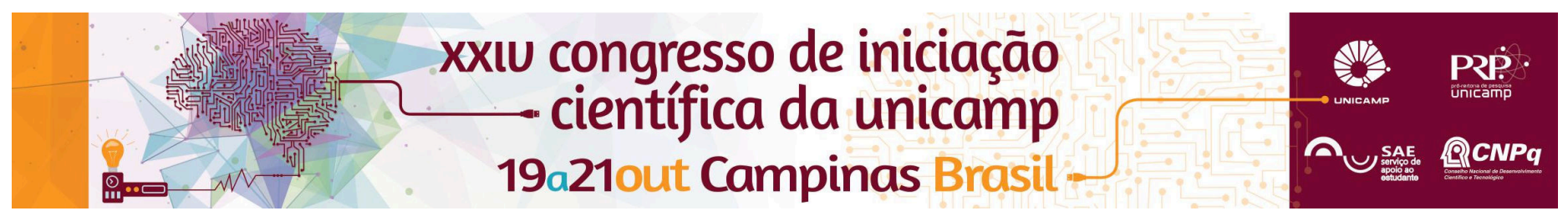

\title{
Despejo irregular de esgoto sanitário no município de Mogi Mirim por meio de fossas
}

\author{
sépticas
}

Thiago A. A. Reis*, Rogério M. Santos, Antoniane A. O. Roque, Ramon Vilela.

\section{Resumo}

A correta destinação para o esgoto sanitário necessita de atenção em decorrência de sua influência nos âmbitos da poluição ambiental, doenças ocasionadas pela falta de saneamento e na poluição de águas subterrâneas, o presente trabalho tem como objetivo mapear os tipos de vícios existentes quanto à destinação inadequada do esgoto sanitário, com uma pesquisa de campo detalhada em três loteamentos de chácaras situadas no município de Mogi Mirim/SP.

\section{Palavras-chave}

Esgoto,saneamento, contaminação.

\section{Introdução}

Segundo dados do IBGE1 apenas $28,5 \%$ do esgoto sanitário coletado nos domicílios brasileiros recebe tratamento e só uma pequena parcela tem destinação final adequada no meio ambiente, e para a $\mathrm{OMS}^{2}$, cerca $19 \%$ de todas as mortes no país poderiam ser evitadas se fossem adotadas políticas públicas eficientes nestes quesitos.

Nos problemas decorridos da falta de cuidados com o esgoto doméstico são geradores de aproximadamente 50 tipos de infecções. Existem duas formas eficientes de destinação final do esgoto, sendo por tubulações até uma estação de tratamento e por meio de fossas sépticas ${ }^{3}$.

A pouca distância entre fossas e poços pode ser considerada um dos grandes causadores do alto índice de contaminação, indicando que o lençol freático pode estar contaminado 4 .

\section{Resultados e Discussão}

O levantamento dos dados foi realizado em três loteamentos de chácaras, localizados em Mogi Mirim/SP, tendo como base os projetos aprovados nos últimos dez anos, no qual foram analisados e visitados 123 imóveis com o objetivo de verificar se as fossas sépticas foram instaladas de acordo com especificações mínimas de projeto, e suas respectivas características são apresentadas na Tabela 1.

Tabela 1. Caracteristicas dos empreendimentos.

\begin{tabular}{|l|c|c|c|}
\hline Tipo de dados & $\begin{array}{c}\text { Chácaras } \\
\text { São } \\
\text { Marcelo }\end{array}$ & $\begin{array}{c}\text { Chácaras } \\
\text { Sol } \\
\text { Nascente }\end{array}$ & $\begin{array}{c}\text { Chácaras } \\
\text { São } \\
\text { Francisco }\end{array}$ \\
\hline Área média & $245,52 \mathrm{~m}^{2}$ & $160,1 \mathrm{~m}^{2}$ & $123,81 \mathrm{~m}^{2}$ \\
\hline $\mathbf{N}^{\circ}$ de quadras & 21 & 15 & 13 \\
\hline Número de Lotes & 346 & 316 & 216 \\
\hline Cadastradas & 276 & 232 & 137 \\
\hline Lotes Baldios & 70 & 84 & 79 \\
\hline Possuem projetos & 69 & 43 & 11 \\
\hline $\begin{array}{l}\text { Atendem as } \\
\text { exigências }\end{array}$ & 3 & 0 & 0 \\
\hline
\end{tabular}

Os resultados obtidos podem ser observados na figura 01.

Figura 1. Resultados da pesquisa de campo.

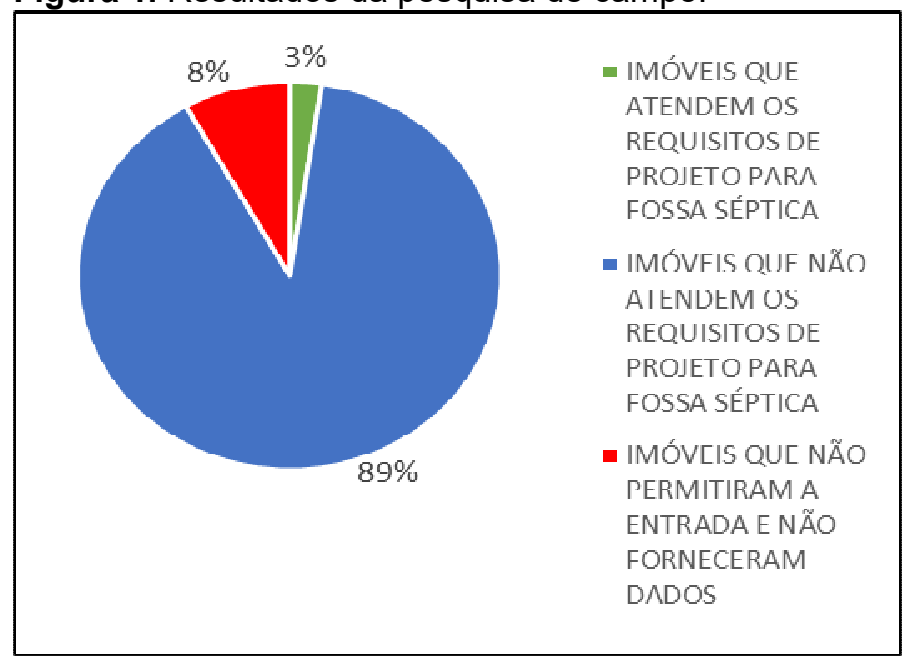

\section{Conclusões}

Com os resultados apresentados pode-se evidenciar que indiferente de classe social e localização, o problema da destinação irregular de esgoto doméstico continua pela população em geral, e os motivos para que isto ocorra são desde vícios culturais até a falta de orientação adequada.

Sugere-se como resultado prático das conclusões apontadas, que os órgãos fiscalizadores e a população em geral, atente-se para a correta destinação do esgoto sanitário, bem como ponderar sobre a importância de se seguir os projetos de engenharia aprovados por órgãos oficiais.

${ }_{1}^{1}$ Pesquisa Nacional de Saneamento Básico 2008. Esgotamento Sanitário. Rio de Janeiro: IBGE, 2008. Disponível em: < http://www .ibge.gov.br/home/estatistica/populacao/ condicaodevida/ pnsb2008 /defaulttabpdf esgot san.shtm/>.Acesso em: out. 2015.

2BBC BRASIL. Doenças ambientais' matam 233 mil por ano no Brasil. Disponível em: < http://www.bbc.com/portuguese/reporterbbc /story/2007/06/070613 oms doencas pu.shtml/>. Acesso em: out. 2015. 3TSUTIYA, M.T. Abastecimeto de água. São Paulo, 2004. ${ }^{4}$ CAMARGO, F. M. Avaliação qualitativa da contaminação microbiológica das águas de poços no município de Carlinda-MT. Disponível em: <http://www.uel.br/revistas/uel/index.php/seminabio /article/view/2903/2461>. Acesso em 04/05/2015. 